\title{
Prevalence of Metabolic Syndrome among Hypertensive Patients Attending a Primary Care Clinic in Kuwait
}

\author{
E.I. Sorkhou B. Al-Qallaf H.A. Al-Namash A. Ben-Nakhi M.M. Al-Batish \\ S.A. Habiba
}

Mishref Family Practice Health Center and Qadisiya Family Practice Health Center, Primary Health Care, Ministry of Health, Kuwait

\section{Key Words}

Metabolic syndrome · Waist · Triglycerides •

Insulin resistance $\cdot$ Primary care

\begin{abstract}
Objective: To determine the prevalence of metabolic syndrome among hypertensive patients using the criteria of the National Cholesterol Education Program's Adult Treatment Panel III in a primary care health center in Kuwait. Subjects and Methods: A population of 250 Kuwaiti hypertensive patients (129 males and $121 \mathrm{fe}-$ males) over the age of 40 were screened for metabolic syndrome by determining body mass index (BMI), waist circumference, levels of fasting plasma glucose and fasting plasma lipids (serum triglycerides, total cholesterol and high-density lipoprotein cholesterol). The study was carried out in the Mishref Family Practice Health Center, Kuwait, from January to July 2001. Results: The total number of patients who met the criteria for metabolic syndrome was $85(34 \%), 55 \%$ of them were males and $45 \%$ females. Prevalence of the syndrome was $28.2 \%$ among 40 - to 55 -year-olds and $41.9 \%$ in those above the age of 55 years. Among the 250 hypertensive patients,
\end{abstract}

\section{KARGER}

Fax +41613061234

E-Mail karger@karger.ch

www.karger.com
(C) 2004 S. Karger AG, Basel

1011-7571/04/0131-0039\$21.00/0

Accessible online at:

www. karger.com/mpp type II diabetes mellitus was found in 52.8\% (54\% males and $46 \%$ females), impaired fasting glucose in $8 \%(70 \%$ males and $30 \%$ females), high plasma triglycerides in $44.8 \%$ (53\% males and $47 \%$ females) and low high-density lipoprotein cholesterol in $63.2 \%(54 \%$ males and $46 \%$ females). Obesity measured as $\mathrm{BMI}=30 \mathrm{~kg} / \mathrm{m}^{2}$ was noted in $46 \%$ ( $43 \%$ males and $57 \%$ females) and increased waist circumference in 58\% (44\% males and $56 \%$ females). Conclusion: The prevalence of metabolic syndrome is high among hypertensives attending primary health care centers in Kuwait.

Copyright $\odot 2004$ S. Karger AG, Basel

\section{Introduction}

Metabolic syndrome is characterized by a constellation of multiple risk factors that include obesity, physical inactivity and genetic factors $[1,2]$. The syndrome is closely associated with a generalized metabolic disorder in which there is a defect in insulin action at the cellular level in the form of impaired responsiveness to endogenous and exogenous insulin (insulin resistance) [3, 4]. Other risk factors include hyperinsulinemia, atherogenic dyslipidemia, and

Dr. Iman Sorkhou

Mishref Family Practice Academic Health Center

Hawalli Health District, Primary Health Care, PO Box 4561

22046 Salmiya (Kuwait)

Tel. +965 5385397/+965 5336810, Fax +965 5385397, E-Mail drsorkhou@hotmail.com 
Table 1. Criteria for diagnosing metabolic syndrome (three or more of the risk factors) according to the National Cholesterol Educational Program's ATP III criteria [5]

\begin{tabular}{ll}
\hline Risk factor & Defining level \\
\hline $\begin{array}{l}\text { Abdominal obesity } \\
\text { Men }\end{array}$ & waist circumference \\
$\quad$ Women & $>102 \mathrm{~cm}(>40$ inches $)$ \\
TG & $150 \mathrm{mg} / \mathrm{dl}$ \\
HDL-C & \\
$\quad$ Men & $<40 \mathrm{mg} / \mathrm{dl}$ \\
$\quad$ Women & $<50 \mathrm{mg} / \mathrm{dl}$ \\
Blood pressure & $130 / 85 \mathrm{~mm} \mathrm{Hg}$ \\
Fasting glucose & $>110 \mathrm{mg} / \mathrm{dl}$
\end{tabular}

high blood pressure. According to the National Cholesterol Education Program of Adult Treatment Panel III (ATP III) guidelines for identifying the syndrome [5], the diagnosis of metabolic syndrome is based upon the demonstration of three or more of the components shown in table 1 . In addition to the criteria in table 1 , the WHO recommends demonstration of microalbuminuria, hyperuricemia, raised levels of plasminogen activator inhibitor-1, and raised fasting insulin level, which is taken as evidence of insulin resistance.

Insulin is a major anabolic regulator of carbohydrate, protein and lipid metabolism and hence is a major growth factor. It stimulates the uptake of amino acids by various cells promoting protein synthesis and inhibiting gluconeogenesis. It also stimulates glucose uptake and its conversion to glycogen. Furthermore, it promotes the synthesis of triglycerides (TG) and its storage as neutral fat. In metabolic syndrome, excess insulin promotes fat storage with consequent weight gain, which is characteristically abdominal. The weight gain in turn further increases insulin resistance, leading to the various abnormalities in plasma glucose and lipids [6, 7]. The causal relationship of the syndrome to hypertension is not clear, but probably relates to the hemodynamic consequences associated with obesity and hyperinsulinemia.

The syndrome has generated much concern over the past few years because it clearly represents a high risk for developing coronary artery disease and cardiovascular events $[8,9]$. The aim of this study was to determine the prevalence of this high risk condition in a population of hypertensive patients attending primary health care.

\section{Subjects and Methods}

A total of 250 Kuwaiti hypertensive patients (129 males and 121 females) above the age of 40 attending the Mishref Family Practice Health Center in Kuwait for follow-up management were screened for the presence of metabolic syndrome from January to June 2001. The patients were randomly chosen on an assigned day, with an average of 10 cases per week. A special form, which included personal data, history of type II diabetes mellitus, measurements of body mass index (BMI), waist circumference, fasting plasma glucose and fasting lipid profile (TG, total cholesterol, high-density lipoprotein cholesterol, HDL-C) was used for data collection. The diagnosis of metabolic syndrome was based on the ATP III criteria [5]. ATP III criteria were chosen over others [10] including those of WHO because their application facilitates diagnosis of metabolic syndrome, particularly at the level of primary health care.

A patient was considered obese if BMI was $=30 \mathrm{~kg} / \mathrm{m}^{2}$, and a diagnosis of abdominal obesity was made when the waist circumference exceeded $102 \mathrm{~cm}$ (40 inches) in males and $88 \mathrm{~cm}$ (35 inches) in females [11]. Hypertriglyceridemia was considered when the fasting $(12-14 \mathrm{~h})$ plasma TG was equal to or exceeded $150 \mathrm{mg} / \mathrm{dl}$ $(1.70 \mathrm{~mm} / \mathrm{l})$ for both males and females. Low HDL-C was determined when the plasma level was less than $40 \mathrm{mg} / \mathrm{dl}(1.04 \mathrm{~mm} / \mathrm{l})$ for males and $50 \mathrm{mg} / \mathrm{dl}(1.3 \mathrm{~mm} / \mathrm{l})$ for females, and hypercholesterolemia was diagnosed when the plasma total cholesterol exceeded $199.6 \mathrm{mg} / \mathrm{dl}(5.2 \mathrm{~mm} / \mathrm{l})$ for both males and females. Diabetes mellitus and impaired fasting glucose were diagnosed in accordance with the American Diabetes Association guidelines [12, 13].

All laboratory tests were done in Mubarak Al-Kabeer Hospital using the Synchron-LX20 clinical System (Beckman, Brea, Calif., USA, 1997). The data were analyzed using the Statistical Package of Social Study SPSS Version 11.0. The $p$ value was derived using the Z-normal test.

\section{Results}

Of the 250 hypertensive patients, $85(34 \%)$ met the ATP III guidelines for diagnosis of metabolic syndrome. The prevalence of each of the five ATP III criteria for diagnosis of metabolic syndrome is shown in table 2 . The criteria with the highest prevalence was reduced high density lipoproteins $(63.2 \%)$, while the lowest was that of impaired fasting blood sugar (8\%). Type II diabetes mellitus and impaired fasting glucose were seen in 52.8 and $8 \%$ of subjects, respectively. High plasma total cholesterol was found in $55.2 \%$, while low HDL-C was detected in $63.2 \%$ of the screened population. Raised plasma TG was found in $44.2 \%$, and increased waist circumference was seen in 58\%. The differences between males and females for impaired fasting blood glucose and increased waist circumference were statistically significant $(\mathrm{p}<0.05)$, while the differences between genders for the remaining criteria were not statistically significant. 
Table 2. Prevalence of each of the ATP III criteria for diagnosis of metabolic syndrome among the screened population $(\mathrm{n}=250)$

\begin{tabular}{lllcc}
\hline Criteria & $\begin{array}{l}\text { Total } \\
\text { subjects, n (\%) }\end{array}$ & $\begin{array}{l}\text { Males } \\
\mathrm{n}(\%)\end{array}$ & $\begin{array}{l}\text { Females } \\
\mathrm{n}(\%)\end{array}$ & $\mathrm{p}$ value \\
\hline Type II diabetes mellitus & $132(52.8)$ & $70(54.2)$ & $62(51.2)$ & $\mathrm{NS}$ \\
Impaired fasting blood glucose & $20(8)$ & $14(10.8)$ & $6(4.9)$ & $<0.05$ \\
Increased waist circumference & $145(58)$ & $57(44.1)$ & $88(72.7)$ & $<0.0001$ \\
Elevated plasma TG & $112(44.8)$ & $59(45.7)$ & $53(43.8)$ & NS \\
Reduced high-density lipoproteins & $158(63.2)$ & $82(63.5)$ & $76(62.8)$ & NS \\
\hline
\end{tabular}

The prevalence of patients with and without metabolic syndrome by gender is shown in table 3 , and the difference between males and females was statistically significant $(\mathrm{p}<0.05)$. The prevalence of metabolic syndrome was $28.2 \%$ for those aged $40-55$ years and $41.9 \%$ for those above the age 55 years. The prevalence of metabolic syndrome among different age groups with and without metabolic syndrome is shown in table 4 , and the difference between the age groups is statistically significant $(\mathrm{p}<$ 0.012).

\section{Discussion}

The prevalence of metabolic syndrome (34\%) in this study was remarkably high, probably because ATP III instead of ATP II criteria [14] were used for the analysis. According to the newer ATP III criteria, low HDL-C is defined as $<40 \mathrm{mg} / \mathrm{dl}(1.04 \mathrm{~mm} / \mathrm{l})$ for males and $<50 \mathrm{mg} /$ $\mathrm{dl}(1.30 \mathrm{~mm} / \mathrm{l})$ for females, while the older ATP II criteria defined low HDL-C as $<35 \mathrm{mg} / \mathrm{dl}(0.91 \mathrm{~mm} / \mathrm{l})$ [14]. When ATP II criteria were applied, the prevalence rate of metabolic syndrome in the current study decreased to $16 \%$, similar to the $17 \%$ prevalence reported by WHO in an earlier study, also using the older guidelines [15]. Thus it appears that the difference in strictness between ATP II and ATP III criteria might in part account for our finding of $34 \%$ prevalence.

A recent study by Ford et al. [16] using ATP III criteria reported unadjusted and age-adjusted prevalence rates of metabolic syndrome of 21.8 and $23.7 \%$, respectively, which is lower than the $34 \%$ prevalence rate of this study. Therefore use of ATP III instead of ATP II criteria may not adequately explain the high rate of prevalence of metabolic syndrome observed in this study. The other plausible explanation is the high prevalence of risk factors such as type II diabetes mellitus, increased waist circumference, elevated plasma TG and reduced high-density lipo-
Table 3. Prevalence of patients with and without metabolic syndrome by gender

\begin{tabular}{llll}
\hline Gender & $\begin{array}{l}\text { Metabolic } \\
\text { syndrome, } \mathrm{n}(\%)\end{array}$ & $\begin{array}{l}\text { Without metabolic } \\
\text { syndrome, } \mathrm{n}(\%)\end{array}$ & $\mathrm{p}$ value \\
\hline Male & $37(43.5)$ & $92(55.7)$ & $<0.05$ \\
Female & $48(56.4)$ & $73(44.2)$ & $<0.05$ \\
Total & $85(100)$ & $165(100)$ & \\
\hline
\end{tabular}

Table 4. Prevalence of patients with and without metabolic syndrome by age

\begin{tabular}{llll}
\hline Age group & $\begin{array}{l}\text { With metabolic } \\
\text { syndrome, } \mathrm{n}(\%)\end{array}$ & $\begin{array}{l}\text { Without metabolic } \\
\text { syndrome, } \mathrm{n}(\%)\end{array}$ & Total \\
\hline Age $=40-55$ & $41(28.2)$ & $104(71.7)$ & 145 \\
Age $=55$ & $44(41.9)$ & $61(58.0)$ & 105 \\
p value & $<0.012$ & $<0.012$ & \\
\hline
\end{tabular}

protein observed in this study (table 2). This view is supported by the close association between hypertension and diabetes mellitus as reported by the American Diabetic Association in which up to $68 \%$ diabetics were also hypertensive [12].

In most cases improper nutrition and inadequate physical activity are the root causes of the syndrome and as such it has been strongly recommended that a healthy lifestyle be adopted that includes weight control [17] and increased physical activity [18-20]. This recommendation is crucial because despite the availability of many medications that can control hypertension, blood sugar and lipids, there is no effective pharmaceutical treatment for raising low HDL-C level. Thus, al- 
though the ATP III guidelines aid in diagnosis of metabolic syndrome, management, to some degree, remains a problem. More studies are needed to identify the syndrome not only in hypertensive subjects, but also in the general population.

\section{Conclusion}

Metabolic syndrome is highly prevalent among hypertensive subjects attending primary health care in Kuwait and therefore we recommend that general practitioners should be aware of this syndrome and should use the ATP III criteria to facilitate the diagnosis of this high risk condition.

\section{References}

1 Meigs JB: Insulin resistance syndrome? Syndrome X? Multiple metabolic syndrome? A syndrome at all? Factor analysis reveals patterns in the fabric of correlated metabolic risk factors. Am J Epidemiol 2000;152:908-911.

2 Timar O, Sestier F, Levy E: Metabolic syndrome X: A review. Can J Cardiol 2000;16: 779-789.

3 Reaven GM: Pathophysiology of insulin resistance in human disease. Physiol Rev 1995;75: 473-486.

4 Granbury MC, Foneseca VA: Insulin resistance syndrome: Options for treatment. South Med J 1999;92:2-15.

5 Executive Summary of the Third Report of the National Cholesterol Education Program (NCEP) Expert Panel on Detection, Evaluation and Treatment of High Blood Cholesterol in Adults (Adult Treatment Panel III). JAMA 2001;285:2486-2497.

6 Scheen AJ, Lefebvre PJ: Insulin action in man. Diabetes Metab 1996;22:105-110.

7 Muller-Wieland D, Krone W: Disorders of lipid metabolism in insulin resistance. Herz 1995; 20:33-46.
8 Wannamethee SG, Shaper AG, Durrington PN, Perry IJ: Hypertension, serum insulin, obesity and metabolic syndrome. J Hum Hypertens 1998;12:735-741.

9 Perry IJ, Wannamethee SG, Walker MK, et al: Prospective study of risk factors for development of non-insulin dependent diabetes in middle aged British men. BMJ 1995;310:560564.

10 Berner A, Lestringant GG, Nyomba BL, Frossard P, Saadi H: Acanthosis nigricans, hyperinsulinaemia and risk factors for cardiovascular disease. East Mediterr Health J 2000;6:H416$\mathrm{H} 424$.

11 Daubresse JC: The importance of syndrome X in daily practice. Rev Med Brux 2000;21:473477.

12 Burke JP, Haffner SM, Gaskill SP, Williams KL, Stern MP: Reversion from type 2 diabetes to nondiabetic status: Influence of the 1997 American Diabetic Association criteria. Diabetes Care 1998;21:1266-1270.

13 The Expert Committee on the Diagnosis and Classification of Diabetes mellitus: Report of the Expert Committee on the Diagnosis and Classification of Diabetes mellitus. Diabetes Care 2002;25:S5-S20.
14 Summary of the Second Report of National Cholesterol Education Program (NCEP) Expert Panel on Detection, Evaluation and Treatment of High Blood Cholesterol in Adults (Adult Treatment Panel II). JAMA 1993;269: 3015-3023.

15 Abdul-Rahim HF, Husseini A, Bjertness E, Giacaman R, Gordon NH, Jervell J: The metabolic syndrome in the West Bank population: An urban-rural comparison. Diabetes Care 2001;24:275-279.

16 Ford ES, Giles WH, Dietz WH: Prevalence of the metabolic syndrome among US adults: Findings from the third National Health and Nutrition Examination Survey. JAMA 2002; 287:356-359.

17 Pogatsa G: From type 2 diabetes to metabolic syndrome. Orv Hetil 1999; 140:635-640.

18 Granberry MC, Fonseca VA: Insulin resistance syndrome: Options for treatment. South Med J 1999;92:2-15.

19 Dodani S, Qureshi R, Ali BS: Syndrome X and family practitioners. J Pak Med Assoc 1999;49: 177-180.

20 Wirth A: Non-pharmacological therapy of metabolic syndrome. Herz 1995;20:56-69. 